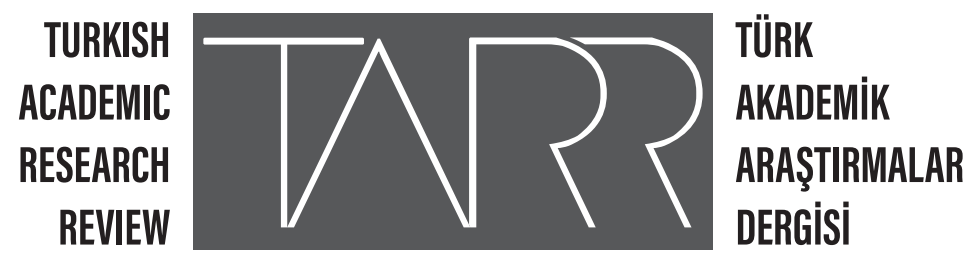

\title{
Müştakzâde Hacı Edhem Efendi'nin Bazı Bestelerinin Makam ve Geçki Yönünden Analizi
}

An Analysis of Maqam and Transitions in Some Musical Pieces Composed by Müştakzâde Hacı Edhem Efendi

\section{Serbülend Arpa}

Dr. Öğr. Üyesi, Ankara Yıldırım Beyazıt Üniversitesi, Türk Musikisi Devlet Konservatuvarı,

Türk Müziği Bölümü, Türk Din Musikisi Anasanat Dalı

e-mail: sarpa@ybu.edu.tr

Orcid 0000-0002-6370-4414

\author{
Makale Bilgisi | Article Information \\ Makale Türü-Article Type | Araştırma Makalesi/Research Article \\ Geliş Tarihi-Date Received | 15 Mayıs / May 2020 \\ Kabul Tarihi-Date Accepted | 25 Haziran / June 2020 \\ Yayın Tarihi-Date Published | 30 Haziran / June 2020 \\ Yayın Sezonu | Nisan-Mayıs - Haziran \\ Pub Date Season | April-May-June
}

Atıf/Cite as: Arpa, Serbülend, Müştakzâde Hacı Edhem Efendi’nin Bazı Bestelerinin Makam ve Geçki Yönünden Analizi/An Analysis of Maqam and Transitions in Some Musical Pieces Composed by Müştakzâde Hacı Edhem Efendi. tarr: Turkish Academic Research Review, 5 (2), 153-174 doi: tarr.739369

İtihal/Plagiarism: Bu makale, en az iki hakem tarafından incelenmiş ve intihal içermediği teyit edilmiştir. / This article has been reviewed by at least two referees and confirmed to include no plagiarism. https://dergipark.org.tr/tr/pub/tarr

Copyright (C) Published by Mehmet ŞAHİN Since 2016- Akdeniz University, Faculty of Theology, Antalya, 07058 Turkey. All rights reserved. 


\title{
Müștakzâde Hacı Edhem Efendi'nin Bazı Bestelerinin Makam ve Geçki Yönünden Analizi
}

\author{
Serbülend Arpa ${ }^{1}$
}

\section{Özet}

II. Mahmud döneminde, 1826 'da Mehterhane'nin lağvedilip yerine Muzıka-yi Hümâyun'un kurulmasıyla birlikte Batı Müziğinin etkisi, Osmanlı İmparatorluğu^nda güçlü bir şekilde hissedilmeye başlamıştır. Osmanlı sarayında gördüğü kabul sayesinde, Batı tarzı tonal müzik, sadece askeri müziğe değil, aynı zamanda klasik Türk Mûsikîsine de etki etmiştir. Bu durum, son dönem Osmanlı müziğinin oluşumuna zemin hazırlamıştır.

Dönemin ünlü bestecilerinden Müştakzâde Hacı Edhem Efendi'nin (ö. 1934) geride bıraktığ1 mûsikî eserleri, 19. yüzyıl Türk Mûsikîsi temayüllerini büyük ölçüde yansıtmaktadır. Müzik eğitimini Muzıka-yi Hümâyun'da alan Müştakzâde, Kadirî tarikatından olması sayesinde aynı zamanda Sufî mûsikîye de derinlemesine vakıftır. Müştakzâde, Bergüzâr-1 Edhem Yahud Ta'lîm-i Usûl-i Mûsikî adlı eserinde, bazı teorik bilgiler yanında çok sayıda güfteyi bir araya getirmiştir. 1890 yılında yayınlanan bu eser, dönemin müzik karakterini tespit açısından oldukça önemlidir.

Makale, Muzıka-yi Hümâyun'un kurumsal tarihini tanıtarak başlamaktadır. Daha sonra Müştakzâde'nin hayatı ve eserleri hakkında genel bilgiler verilmiş özellikle Bergüzâr-1 Edhem Yahud Ta'lîm-i Usûl-i Mûsikî adlı eseri ile ilgili çeşitli hususlara değinilmiştir. Sonraki aşamada, ikisi dinî, ikisi lâdînî temalı olmak üzere Müştakzâde tarafindan bestelenmiş dört eserin müzikal açıdan analizi yapılmıştır.

Bu çalışmada; Müştakzâde Hacı Edhem Efendi'nin kendine has bir tavır ve tarz ortaya koyduğu, bestelerinde kullandığı makamları işlerken klasik eserlerde pek rastlanmayan geçki ve çeşnilere yer verdiği, bu çeşit yorumların onun çok yönlü mûsikî anlayışına sahip olduğuna işaret ettiği sonucuna varılmıştır.

Anahtar Kelimeler: Hacı Edhem Efendi, Müzik, Beste, Makam, Analiz.

1 Dr. Öğr. Üyesi, Ankara Yıldırım Beyazıt Üniversitesi, Türk Musikisi Devlet Konservatuvarı, Türk Müziği Bölümü, Türk Din Musikisi Anasanat Dal1; E-Posta: sarpa@ybu.edu.tr; Orcid: 0000-0002-6370-4414. 


\title{
An Analysis of Maqam and Transitions in Some Musical Pieces Composed by Müștakzâde Hacı Edhem Efendi
}

\begin{abstract}
The influence of western music started to be felt strongly in the Ottoman Empire with the establishment of the Muzıka-yi Hümâyun (The Imperial Music School) during the reign of Mahmud II, instead of Mehterhane (The Janissary Band) that was dissolved in 1826. Due to the Ottoman palace's accommodation, the western-style tonality resonated not with the military music only but also Turkish classical music. It paved the way for the formation of the late Ottoman music.

The legacy of Müştakzâde Hacı Edhem Efendi (d. 1934), one of the famous composers of the time, reflects on a great scale the trends of the 19th-century Turkish music. He received his music education in Muzıka-yi Hümâyun. However, he had good knowledge of Sufî music thanks to his Qadirî background. In his work titled Bergüzâr-1 Edhem Yahud Ta'lîm-i Usûl-i Mûsikî (Edhem's Heirloom or Music Rhythms Training), he compiled a good number of song lyrics alongside with some theoretical information. Published in 1890, this work is such an important resource that we have in terms of determining the musical character of the period.

Starting by introducing to Muzıka-yi Hümâyun, the article gives a brief account of Müştakzâde's life, works, and different aspects of his Tribute. Then it contains a musical analysis of four pieces composed by him, two of which were about religious themes while the other two are not.

Outcomes of this study conclude that Müştakzâde Hacı Edhem Efendi had a unique musical style and that maqam transitions he used in his compositions are quite different from what we see in other classical works. These features make him an original composer in many ways.
\end{abstract}

Keywords: Hac1 Edhem Efendi, Music, Composition, Maqam, Analysis.

\section{Giriș}

Batı müziğinin Osmanlı'daki etkisinin güçlü bir şekilde hissedilmesi 19. yüzyıla tekabül eder. Özellikle II. Mahmud'un 1826 y1lında Yeniçeri Ocağı ile birlikte Mehterhâneyi ilga etmesinden sonra Muzıka-yi Hümâyun'un (Özcan, 2006, s. 422) (1827) kurulması, tonal müziğin saraya girmesine ve Türk Mûsikîsinin daha ziyade tekkelere çekilmesine (Sefer, 2012, s. 71) sebep olmuştur. Bu dönemde saray tarafindan desteklenen Batı Müziği sadece askerî müziğe değil klasik beste üsluplarına da etki ederek bu bestelerin 20. yüzyıl Türk Mûsikîsini şekillendirmesine zemin hazırlamıştır.

1928 yılında Giuseppe Donizetti’nin “ustakâr” sıfatıyla Muzıka-yı Hümâyun'un başına getirilmesi ile başlayan ve 1868 y1lında Callisto Guatelli ile devam eden bu süreçte İtalyan-Fransız müzik ekolünün etkili olduğunu (Karagül, 2019, s. 41) söyleyebiliriz. Muzıka-yı Hümâyun 
içinde sonradan kurulan Türk Mûsikîsi bölümünde "Fasıl Heyeti (Fasl-1 Atîk, Fasl-1 Cedîd)"ve "Müezzinân” kısımları (Özcan, 2006) bulunsa da Fasl-1 Cedîd tarafından icra edilen eserlerde flüt, gitar, trombon gibi batı sazlarının kullanılması (Güdek \& Kılıç, 2016, s. 92) ve bestelerin armonize edilmesiyle tonal müziğin Klasik Türk Mûsikîsi üzerindeki hakimiyeti iyiden iyiye hissedilmeye başlamıştır.

19. yüzyıldaki bu gelişmeleri ve Türk Mûsikîsinin durumunu yansıtması açısından dönemin bestekârlarından Muzıka-yi Hümâyun tahsilli Kadiri Şeyhi Müştakzâde Hâfız Edhem Efendi'nin önemli bir yeri olduğunu düşünüyoruz. Zira Edhem Efendi hem tekke hem de Muzika-yi Hümâyun eğitiminden geçen ve bestekârlık özelliği olan ender şahsiyetlerden biridir. Onun bestelerinde Türk Mûsikîsi makamlarının nasıl işlendiğini tespit etmek dönemin mûsikî anlayışına 1şık tutacaktır. Ayrıca bestekârın güfte yazma özelliği ve "Bergüzâr-ı Edhem Yahud Ta'lim-i Usûl-i Mûsikî" (1890) adlı bazı mûsikî bilgilerinin de bulunduğu güfte mecmuasını neşretmesi (Edhem Efendi, 1307) dönemi anlamak açısından elimizde bulunan önemli bir kaynak özelliğini taşımaktadır.

\section{Amaç ve Yöntem}

Bu çalışma; Osmanlı'nın son dönemlerinde dinî ve lâdinî (din dışı/profan) besteleriyle öne çıkmış olan Müştakzâde Hâfız Edhem Efendi'nin mûsikî kişiliğini ve tarzını anlayabilmek için bestekâra ait dört eserinin makam ve geçki yönünden analizini yapmayı amaçlamaktadır. Müştakzâde Hâfız Edhem Efendi'nin bir taraftan Kâdirî Tekkesinde yetişmesi sebebiyle dini mûsikîye aşina olması diğer taraftan mûsikî eğitimini batı müziği tesirinin çokça hissedildiği dönemde Muzıka-yi Hümâyun'da alması bizi bu çalışmaya yönlendiren sebeplerden biri olmuştur. Zira dönemin bestekârlarının ürünlerini analiz etmek Türk müziğinin Meşrutiyet dönemine tekabül eden yıllardaki durumuna ışık tutması açısından önem arz etmektedir.

Seçkisiz örnekleme (tabakalı) yöntemiyle bestesi Müştakzâde Hâfız Edhem Efendi'ye ait 2 adet dinî, 2 adet lâdinî eserin seçilerek müzikal analizinin yapıldığı bu çalışmada, bestekârın hayatı ve eserleri hakkında kısa bilgiler verildikten sonra makâm ve geçki analizine geçilmiştir. Eserlerin nazarî olarak incelenmesinde Arel-Ezgi-Uzdilek sistemi temel alınmıştır. Ancak

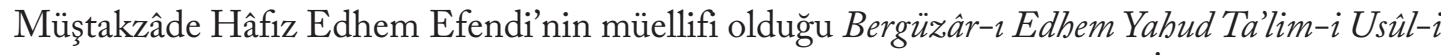
Mûsikî (1890) adlı güfte mecmuasının 9. sayfasındaki "Sadâların Alaturka İsimleri” bölümünden ve 11,12,13. sayfalarındaki makam tariflerinin yer aldığı bölümden bestekârın 17'li perde sistemini benimsediği anlaşılmaktadır (Edhem Efendi, 1307; Feyzi, 2014, ss. 165, 166). Bir oktavı 17 perdeye taksim eden sistemin kökleri Safiyyüddin El-Urmevîye (ö. 1294) kadar uzanmaktadır. Bu nedenle yaptığımız analizde kullandığımız makam, perde, aralık, geçki, çeşni vb. kavramlar ile mezkur mecmuada bestekâr tarafindan kullanılan kavramlar arasında farkl1liklar bulunmaktadir.

Eserler Mus2 (Sürüm 2.1.5) isimli program kullanılarak notaya alınmıştır. Bu aşamada hangi nüshalarının esas alındığı hususunu şu şekilde özetleyebiliriz; 
“Zirgüleli Sûzinak Tevşih” başlıklı eserin yeniden notaya alınması esnasında 08.02.1998 tarihli, H. Alvan imzalı nota esas alınmış, ayrıca 18.11.1947 tarihli ve Cüneyt Kosal imzalı nüshadan faydalanılmıştır.

“Uşşak Cumhur İlahi” başlıklı eserin yeniden notaya alınmasında ise Y. Ömürlü imzalı tarihsiz nota ve 08.12.1947 tarihi bulunan Cüneyt Kosal kaşeli nota esas alınmıştır.

"Bir Nigâh Et Bana Çeşmânına Hayrân Olayım” (T.R.T, T.S.M Rep. No: 2189) adlı Uşşak Şarkı yeniden notaya alınırken 3 farklı nüshadan faydalanılmıştır. Bunlardan ilki Cüneyt Kosal tarafından "Muallim İsmail Hakkı Beyin TRT'deki Kolleksiyonundan yazıldı. Güfte ilave edildi." notuyla beraber yazılan notadır. İkincisi “Chant Turc (Türkçe Şarkı)” başlı̆̆ıyla hazırlanmış Fransızca nota mecmuasındaki C. Guatelli ${ }^{2}$ tarafından armonize edilerek Hakkâk Servitchen Taş ve Hurufât Matbaası'nda ${ }^{3}$ basılan Hacı Emin imzalı notadır. Güftesi Osmanlıca yazılmış olan ve tarihine rastlayamadığımız bu nüshada bazı farklılıklar bulunmaktadır. Üçüncüsü Şam$1_{1} \mathrm{Selim}^{4}$ imzalı olan ve Evfer usulünde yazılıı̧ Osmanlıca güfteli notadır. Bu notada da küçük farkliliklar bulunmaktadir.

“Gönlüm Yine Bir Âteşi Hicrâne Dolaştı” (T.R.T, T.S.M Rep. No: 5145) adlı Nihâvend Şarkıda ise yazılmış pek çok notadan faydalanılmıştır. Bunların içinde güftesi Osmanlıca yazılmı̧̧ olan Cüneyt Kosal kaşeli nüshasının üzerindeki metin silinmiş olduğundan bu nüshanın tarihine ulaşılamamıştır.

\section{Müștakzâde Hacı Edhem Efendi (Șeyh) (1854/60/62-1933/1934)}

İsminin önüne Şeyh, Hacı, Hafız, Hânende, Bahriyeli (Tersaneli) ve Müştakzâde sıfat/unvanları getirilerek de anılmaktadır. İstanbul Fatih'te bulunan Hoca Hayreddin Paşa Mahallesi'nde dünyaya gelmiştir (Özcan, 1994, s. 417). Doğum tarihi hususunda kesin bir tarihe ulaşılamamaktadır. Ancak 1854, 1860 ya da 1862 y1lında doğduğuna dair bilgiler mevcuttur (Rona, 1970, s. 34; İnal, 1958, s. 177; Öztuna, 1990, s. 185). Babas1 Kadirî Kadı İsmail Hakkı Efendi, annesi Hadice Hayriye Hanım'dır (Öztuna, 1990, s. 185). 1874 yılında babasının vefatı üzerine Şeyhülislam Hacı Kara Efendi’nin himayesine girmiş ve onun terbiyesi altında yetişmiştir. Dinî tahsili Fâtih Camii'nde aldığı derslere dayanmaktadır. Hocaları arasında Karinâbâdlı Ömer Efendi, Şumnulu Hâfız İbrahim Efendi, Ödemişli İbrâhim Efendi ve Köprülülü Mahmud Efendi vardır (Özcan, 1994, s. 417; Koca, 2017, ss. 49-51). Burada hâfızlığını da tamamlayarak Muzıka-yi Hümâyun'a devam etmiş, Aziz Mahmud Bey ve Sıdkı Beylerden dinî ve ladinî eserler meşk etmiştir. Fındıkzâde'deki evinde mûsikî dersleri vermiş, daha sonra bu derslere Fatih Çarşamba'daki evinde devam etmiştir (Öztuna, 1990, s. 185).

2 Callisto Guatelli (Guatelli Paşa): (1819-1899) Giuseppe Donizetti’nin 12 Şubat 1856'daki vefatından sonra yerine; Pera'daki Naum Tiyatrosunda orkestra şefliği yapan İtalyan Callisto Guatelli getirilmiştir. 1856'da Muzıka-1 Hümayün'ün komutanlığına atanmıştır. Guatelli Paşa'nın çok sesli müziğin Osmanlı topraklarında gelişimi için yaptığı çalışmaların yanı sıra Türk müzisyenlerin yetişmesine de büyük katkısı vardır (Kutlay Baydar, 2010, ss. 288-289).

31908 Yılında çıkmış Annuaire Oriental'daki Matbaacılar Listesinde yer almaktadır (Yıldırım, 2019, s. 251).

4 Şamlı Selim (Kutmani): Şam'da doğmuş ve 1876-1942 yıllarında arasında yaşamış olan Kanun yapımcısı Davut Efendi’nin üç çocuğundan en büyük olanıdır. İstanbul Vezneciler'de 1900 yılında nota yayıncılığına başlamıştır. Türk müziği ile ilgili en fazla nota yayını yapan kişilerden biridir (Sezen, 1992, s. 18). 
Evkâf-1 Hümâyun Nezâreti Muhasebe Kalemi'nde göreve başlamış, 1883'te buradan Bahriye Nezâreti'ne geçmiş, 1892 yilında hacca giderek dokuz ay (Öztuna, 1990, s. 185) ya da üç buçuk ay Medine'de kalmıştır (Özcan, 1994, s. 417). Burada kaldığ1 dönemde okuduğu Türkçe mevlid hacıların beğenisini kazanmış, icra tarzına kaynaklarda yer verilmiştir (İhsanoğlu vd., 2003, s. 210; İnal, 1958, s. 178; Özcan, 1994, s. 417).

İntisap ettiği hocası Köprülülü Mahmud Efendi’nin 1891 yllında vefat etmesi üzerine Bă̆datlı Said Efendi'den Nakşibendiyye icâzeti almış, 1916'da Fethiye civarında Kefevî Tekkesi'ne Kâdirî şeyhi Arap Said Efendi'nin halifesi olarak vekâleten, bir müddet sonra da asaleten tayin edilerek 1925 yılına kadar bu görevde kalmıştır (Özcan, 1994, s. 417).

Hoş meşrep, halîm ve mütevâzı bir kişiliğe sahip olan Hacı Edhem Efendi (Rona, 1970, s. 34), farklı formlarda 170 civarında eser bestelemiş (Öztuna, 1990, s. 185), bu eserlerden 142'sinin

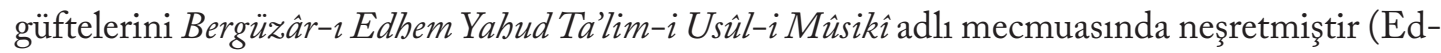
hem Efendi, 1307; Feyzi, 2014, ss. 170, 174-178). Ayrıca Hâfız Sâmi, Hâfız Kemal, Neyzen Süleyman Erguner/Dede ve Arap Cemal gibi öğrenciler yetiştirmiştir (Öztuna, 1990, s. 185).

Hacı Edhem Efendi 1933 ya da 1934 yılında vefat ederek Edirnekapı mezarlığına defnedilmiştir (Özcan, 1994, s. 417; Öztuna, 1990, s. 185; Rona, 1970, s. 34). Şevki Bey ile yakın dost olan Hacı Edhem Efendi (İhsanoğlu vd., 2003, s. 210), şiirlerinde "İlhâmî" mahlasını kullanan üslup sahibi bir bestekâr olarak tanınmıştır. (Özcan, 1994, s. 417).

On dokuzuncu yüzyılın ikinci yarısında isim yapmı̧̧ bestekârlar arasında "Edhem" ismiyle tanınan üç bestekâr vardır (Feyzi, 2014, s. 163). Bunlar; Kanuni Edhem Efendi (Kolağası), Santuri Edhem Efendi (Santuri Büyük İbrahim) ve Şeyh Edhem Efendi (Müştakzâde)'dir. Bazı eserlerin hangi “Edhem Efendi”ye ait olduğu hususu günümüzde hala tartışma konusudur.

\section{Hâfız Edhem Efendi’nin Bazı Eserlerinin Müzikal Analizi}

\section{Zirgüleli Sûzinak Tevșih}

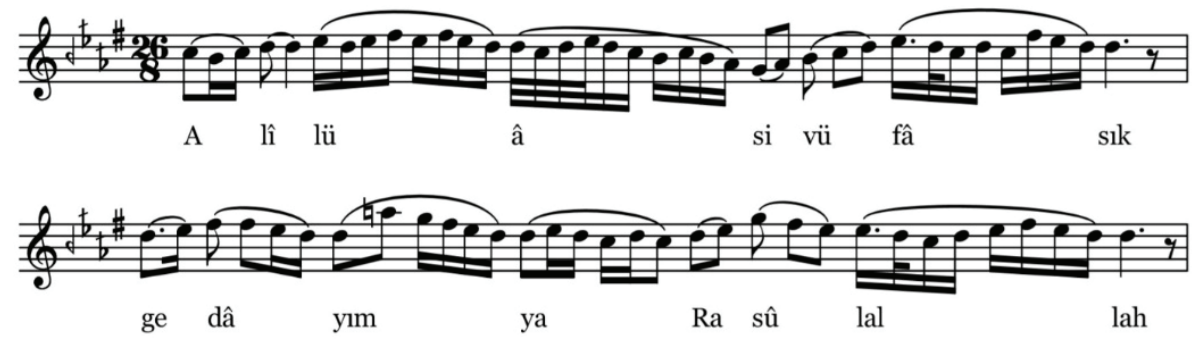

Şekil 1. Eserin 2 ölçülük zemin bölümü.

Eser evsat usulüyle bestelenmiştir. Zirgüleli Sûzinak makamı inici-çıkıcı seyir özelliği gösterdiğinden dolayı ilk ölçüye çargâh perdesiyle nevâ perdesi civarından giriş yapılmıştır. Nevâ perdesi civarından seyre başlanması Zirgüleli Sûzinak makamının karakteristik özelliğidir. Nevâ 
perdesinde Hicaz gösterildikten sonra rast perdesi üzerinde Zirgüleli Hicaz gösterilmiştir. Daha sonra tekrar neva perdesi üzerinde Hicaz göstererek bu perdede yarım karar yapılmıştır. İkinci ölçüye yine nevâ perdesindeki Hicazla devam edilmiştir. Ancak burada kullanılan muhayyer perdesi nevâ üzerinde hicaz 5'lisini meydana getirmiştir. Zirgüleli Sûzinak makamında pek rastlanılmayan bu durum bestekâra özgü bir yorum olarak düşünülebilir. Ölçüye nevâ perdesi üzerinde Hicaz işlenerek devam edilmiş, yine nevâ perdesinde yarım karar yapılarak nakarata bağlanmıştır.

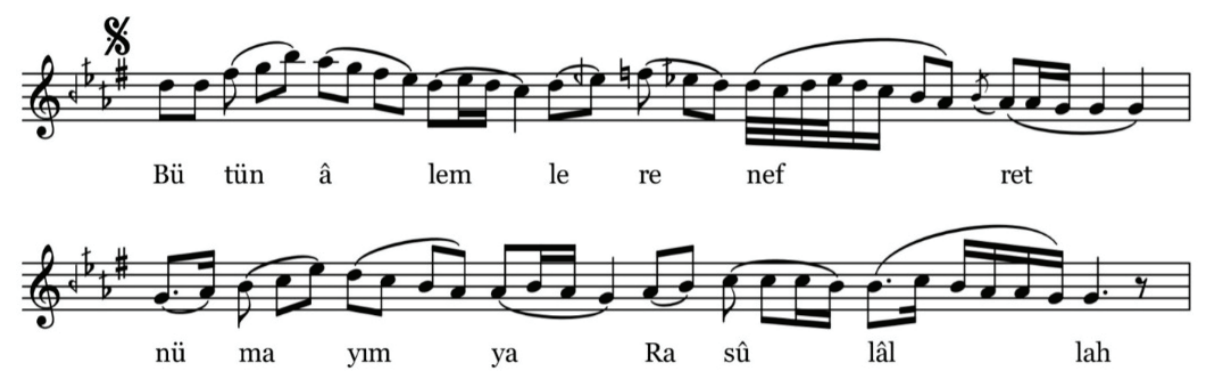

Şekil 2. Eserin 2 ölçülük nakarat bölümü.

Eserin nakarat bülümüne nevâ perdesiyle giriş yapılmış, gerdaniye perdesinden tiz segâh perdesine atlama yapılarak dönüşünde Hicaz gösterilmiş, hemen arkasından nevâ perdesinde Hicaz ve sonrasında çargâh perdesinde Nikriz gösterilmiştir. Arkasından nevâ perdesinde Uşşak geçkisine yer verilmiş, hisar perdesinden rast perdesine kadar Zirgüleli Suzinak dizisini oluşturan perdeler gösterilmiştir. Nakaratın ikinci ölçüsünde rast perdesindeki Zirgüleli Hicaz iki kere işlenerek makamın temel yapısı güçlendirilmiştir.

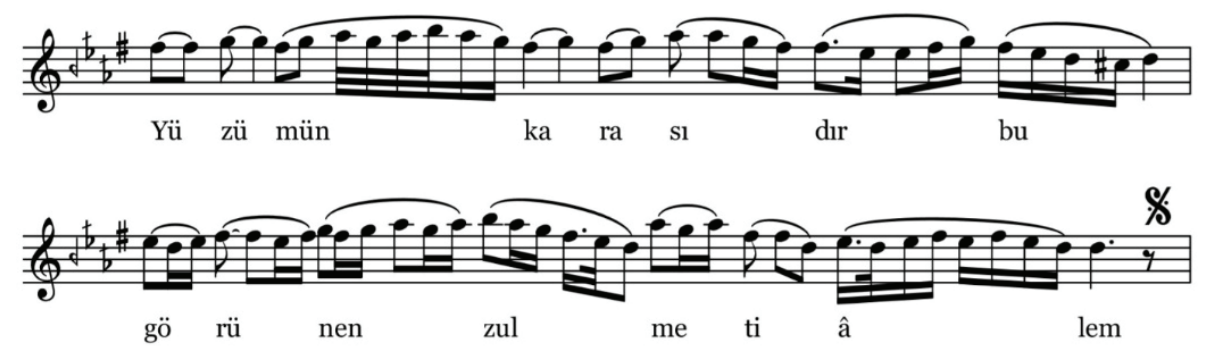

Şekil 3. Eserin 2 ölçülük meyan bölümü.

Eserin meyan bölümüne Zirgüleli Hicaz makamı seyrinde pek karşılaşmadığımız eviç perdesiyle giriş yapılmış ve gerdaniye perdesi civarında Zirgüleli Hicaz işlenmiştir. Eviç perdesi ile giriş yapılmasının sebebinin, yeden gösterilerek gerdaniye perdesi üzerindeki Zirgüleli Hicaza bağlantı yapma arzusu olduğunu düşünmekteyiz. Bu ölçüde yine Hicaz gösterilerek seyre devam edilmiş ve nihayetinde nevâ perdesi güçlendirilerek üzerinde nim hicaz perdesiyle yarım yedenli kalış yapılmıştır. İkinci ölçüde klasik makam anlayışına uygun olarak seyre yine nevâ ve gerdaniye perdelerindeki Hicazla devam edilmiş ve nevâ perdesindeki kalışla nakarata bağlantı yapılmıştır. 


\section{Cumhur İlahi (Ușșak)}
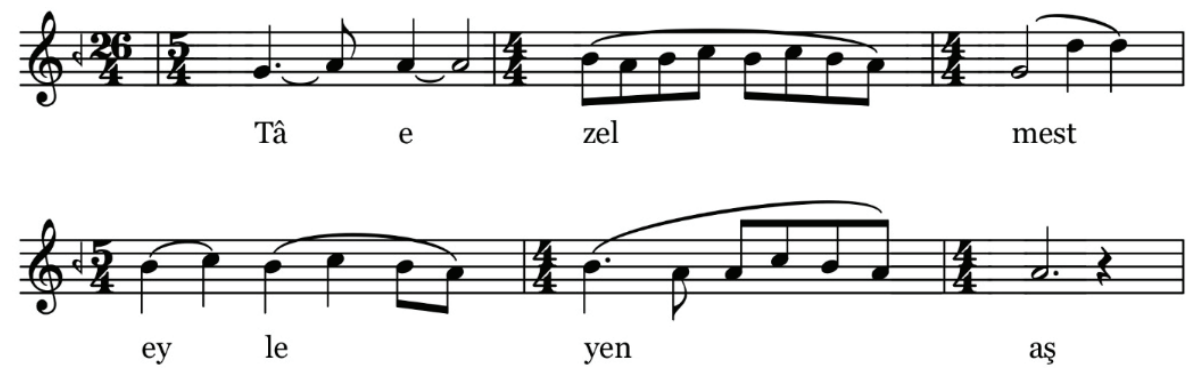

Şekil 4. Eserin zemin bölümünü oluşturan ilk ölçüsü. (Evsat usülü altı parça halinde gösterilmiştir)

Eser evsat usulünde bestelenmiştir. Giriş bölümüne Uş̧̧ak makamının karakteristik özelliği olan dügâh perdesi civarından başlanmıştır. Uşşak makamına rast perdesinden giriş yapılması sıklıkla görülmektedir. Dügâh ile nevâ perdeleri arasında uşşak 4'lüsünü gösterip giriş seyrini yaptıktan sonra satır sonundaki ölçüde de görüleceği üzere rast perdesinden nevâ perdesine atlanarak uş̧̧ak makamının güçlüsü olan nevâ perdesi tutulmuş, akabinde uşşak 4'lüsünü oluşturan perdelerde gezinerek nihayetinde karar perdesi olan dügâh perdesine gelinmiştir.

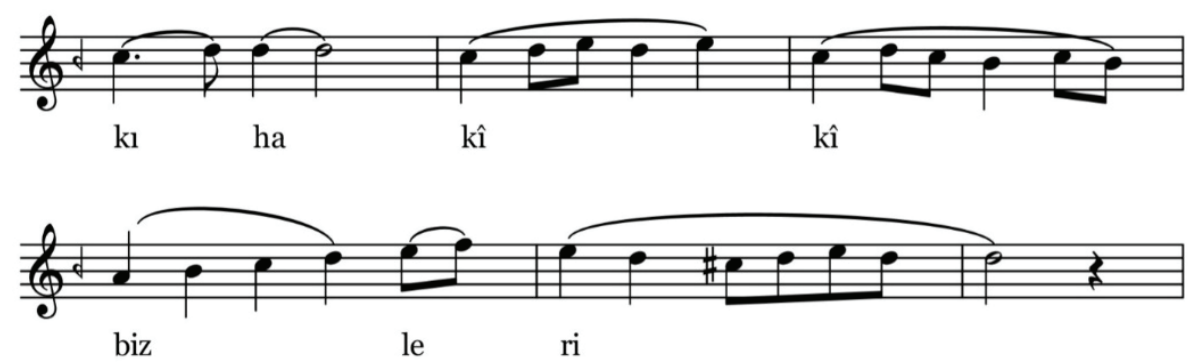

Şekil 5. Eserin zemin bölümünü oluşturan ikinci ölçüsü. (Evsat usülü altı parça halinde gösterilmiştir)

İlk satırda uş̧̧ak 4'lüsünü oluşturan perdelere hüseynî perdesi eklenmiş, bu perdelerde gezinti yapıldıktan sonra ikinci satırdaki dügâh perdesine düşüş yapılmıştır. İkinci satırda acem perdesine kadar çıkılmış, dönüşünde nim hicaz perdesine kadar gelinmiş, bu perde yeden kabul edilerek Uşşak makamının karakteristik özelliği olan nevâ perdesinde Bûselikli kalış yapılmıştır. 


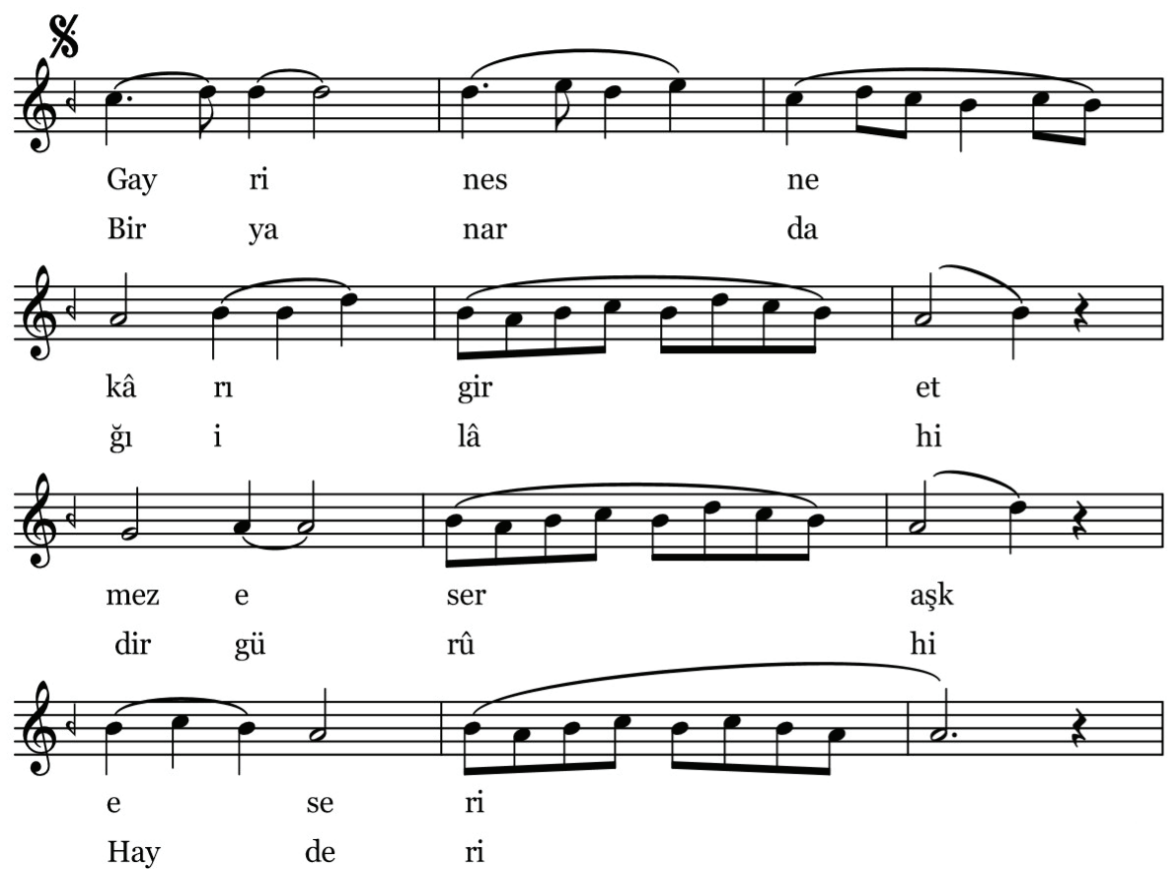

Şekil 6. Eserin 2 ölçülük nakarat bölümü. (Evsat usülü altı parça halinde gösterilmiştir)

Nevâ perdesindeki kalışın ardından eserin nakarat bölümüne gelindiğinde ilk satırda; hüseynî perdesi de eklenerek uşşak 4'lüsünün işlendiğini söyleyebiliriz. İkinci satırda eserin geneline hâkim olan uşşak 4'lüsü civarlarının işlenmesine devam edilmiş satır sonunda segâh perdesinde asma kalış yapılmıştır. Bu asma kalış güçlü bir Uş̧̧ak makamı hissi vermekle beraber dügâh perdesine gidiş hissi de vermektedir. Zira Uş̧̧ak makamının seyrinde dügâh perdesine gidilirken segâh perdesindeki kalışlar sıklıkla görülür. Nitekim üçüncü satırda yedeni ile beraber uş̧̧ak 4'lüsü işlenmiş ve satır sonundaki nevâ perdesindeki kalışla güçlü olan Uşşak duygusu devam ettirilmiştir. Dördüncü satırda ise Uş̧̧ak makamında yine sıklıkla görülen segâh perdesindeki kalkışla dügâh, segâh ve çargâh perdelerinde gezinmeye devam ederek nakarat bölümünü dügâh perdesiyle tamamlanmıştır. 

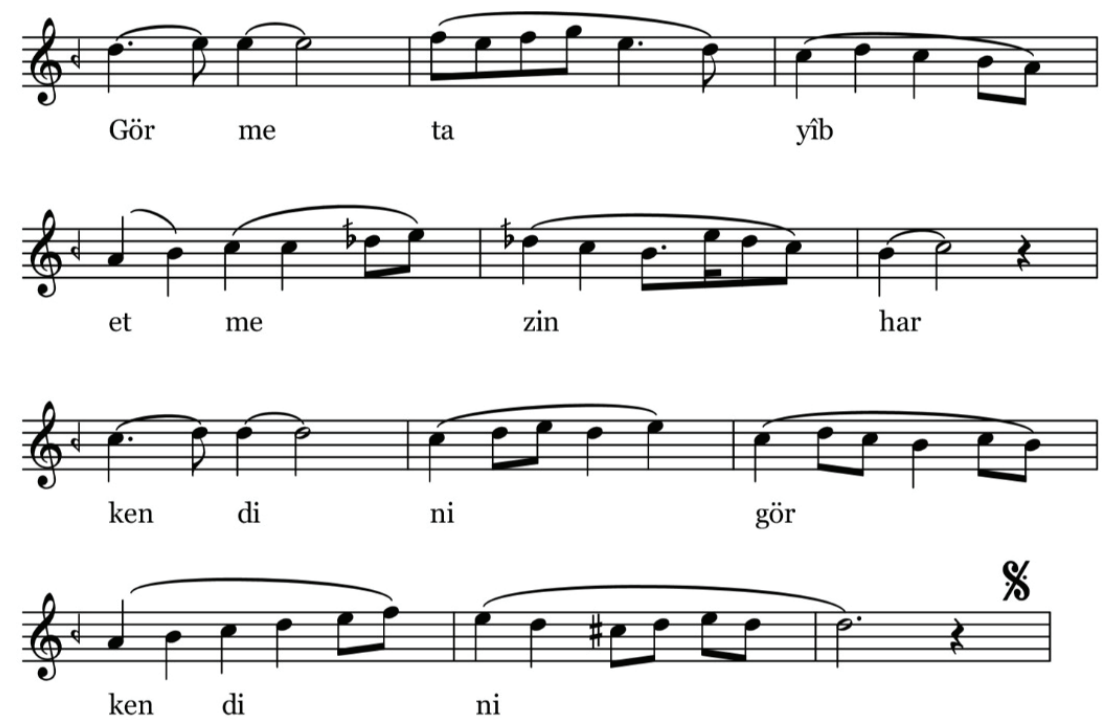

Şekil 7. Eserin 2 ölçülük meyan bölümü. (Evsat usülü altı parça halinde gösterilmiştir)

İlk satırdaki meyan bölümüne girişte her ne kadar nevâ perdesi kullanılmış olsa da bestekârın hüseynî perdesini güçlendirdiğini görmekteyiz. Bunun sebebinin meyan bölümünü zenginleştirme arzusu ve ikinci satırda göreceğimiz Sabâ geçkisini daha yumuşak yapabilme hazırlığ olduğunu düşünmekteyiz. İkinci satıra gelindiğinde hicaz perdesi kullanılarak Sabâ geçkisi yapıldığını görüyoruz. Satır sonunda ise çargâh perdesinde asma kalış yapılmıştır. Üçüncü ve dördüncü satırda bestekârın yine nevâ perdesinde Bûselik aralıkları kullanarak ve Uşşak makamı dizisinde bulunan perdeleri kullanarak eserin nakarat bölümüne bağlantı yaptığını ifade edebiliriz.

\section{Bir Nigâh Et Bana Çeșmânına Hayrân Olayım (Ușșak Șarkı)}

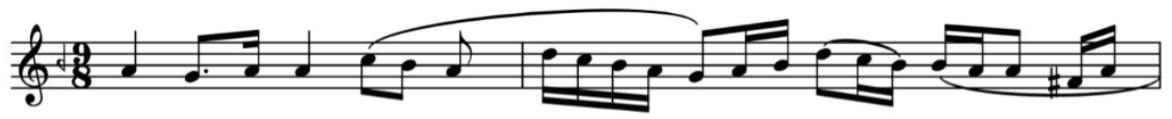

Ah Bir ni gâh et

ba na çeş mâ
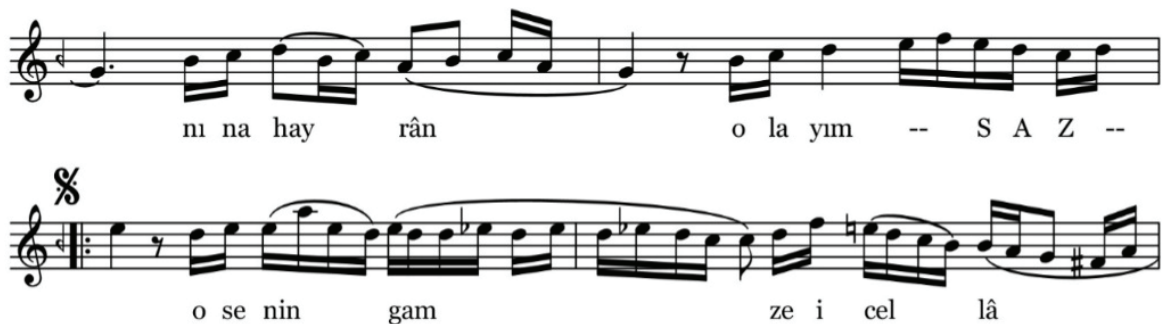

Şekil 8. Eserin 4 ölçülük zemin bölümü. 
Şarkı aksak usulünde bestelenmiştir. Seyre Uşşak makamının özelliği olan dügâh perdesi civarından başlanmıştır. ${ }^{5}$ İkinci ölçüye de Uş̧̧ak seyriyle devam edilmiş ancak ölçü sonundaki Aksak usûlünün son darbında bir sonraki ölçünün rast perdesinde kalışına hazırlık yapıldığı görülmüştür. Nitekim sonraki ölçüde rast 5'lisi gösterilerek Rast makamına geçiş yapılmıştır. Bu durum Uşşak makamı seyrinde sıklıkla görülmektedir. Zira Uşşak makamının yedeni olan rast perdesine vurgu yapılarak nihayetinde bu perde üzerinde kalış yapılması doğal rast 5’lisini ortaya çıkartmaktadır. Dördüncü ölçüye yine rast perdesinden giriş yapılmış ve saz bölümüne kadar Rast makamı hissi korunmuştur. Ancak zemin bölümünden nakarat bölümüne geçişi sağlayan saz bölümünde Uşşak makamında az rastlanan hüseynî perdesine vurgu yapılmıştır. Bu bağlantı cümlesinde her ne kadar Hüseynî makamı çeşnisi hissedilse de bestekârın Karcığar geçkisi hazırlığı hissini verdiğini de söyleyebiliriz.

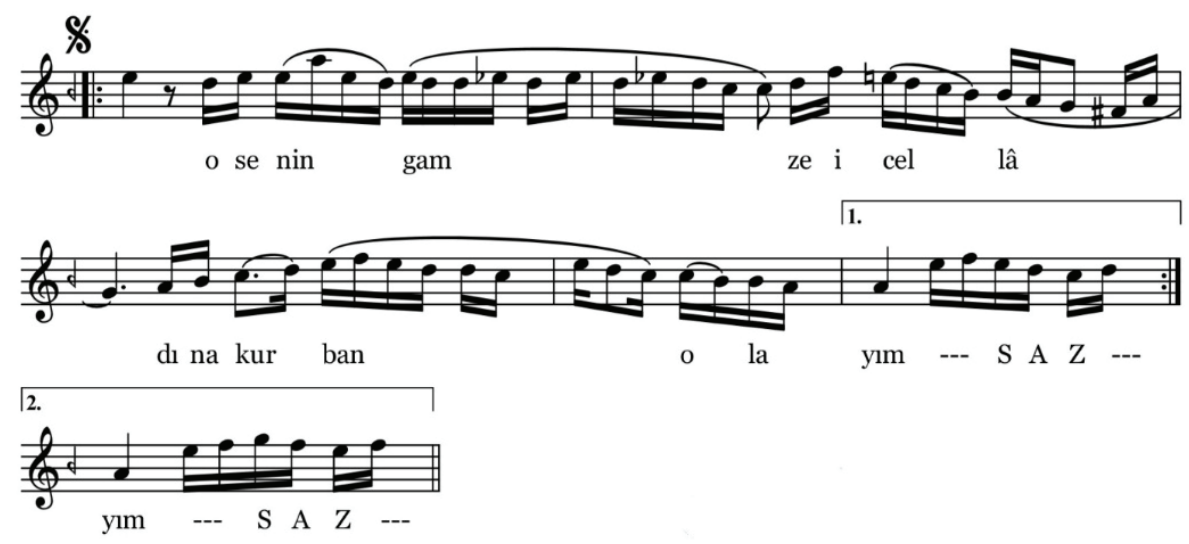

Şekil 9. Eserin 6 ölçü ile gösterilen nakarat bölümü.

İlk ölçüde bestekârın bir önceki ölçüde bulunan hüseynî perdesi vurgusunu güçlendirdiğini görüyoruz. Ölçünün devamında karakteristik olarak Karcığar melodileri bulunsa da eviç perdesi bulunmadığından nevâ perdesinin üzerine kurulu bir hicaz aralığından söz edemiyoruz. Bu nedenle Karcığar ya da Sûzinak geçkisinin yapıldığını söyleyemeyiz. İlk ölçüyü ikinci ölçünün ilk darbıyla beraber değerlendirdiğimizde Karcığar hissi veren bu seyir acem perdesinin kullanılmasıyla değişmektedir. Üçüncü ölçünün ilk darbına kadar olan bölümde Rast makamını oluşturan perdelerin rast ve acem perdeleri arasında kullanıldığını, bu nedenle güçlü bir Rast makamı hissi oluşturduğunu söyleyebiliriz. Üçüncü ve dördüncü ölçüyü beraber değerlendirdiğimizde ilk darptan sonra dügâh perdesinden tekrar acem perdesine çıktığını ve bazı iniş çıkışlar yaparak nihayetinde dügah perdesinde karar verdiğini görebiliriz. Birinci dolap ve meyana saz geçişi bölümlerindeki bağlantı cümlelerinde yine hüseynî perdesine vurgu yapıldığını görmekteyiz. Uş̧̧ak seyrinde az rastlanan bu bağlantıların eserin karakteristik özelliğini yansittı̆̆ını ifade edebiliriz.

5 Hacı Edhem Efendi Uş̧̧ak makamını şöyle tarif etmektedir: Uş̧̧ak; Rast, dügâh girip segâh, dügâh, rast ile dügâhta kalır (Edhem Efendi, 1307, s. 11). 


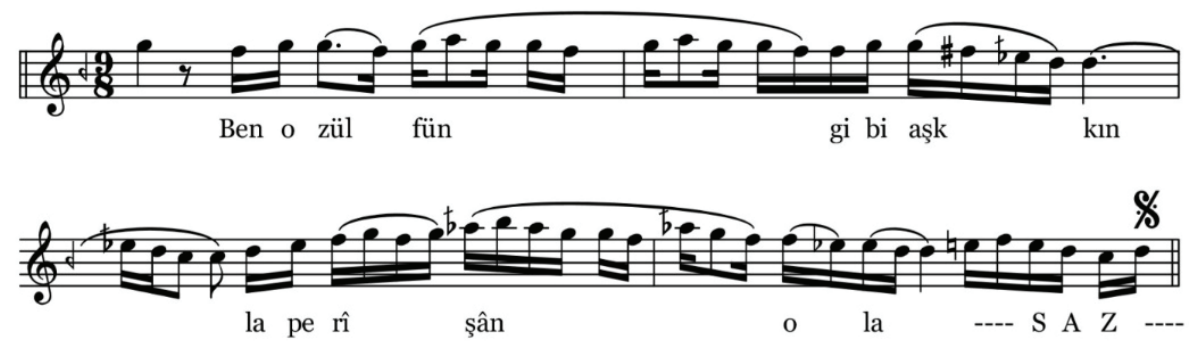

Şekil 10. Eserin 4 ölçülük meyan bölümü.

Eserin meyan bölümünü kaynak notaların farklı olması sebebiyle iki şekilde değerlendirmeyi uygun gördük.

Şekil 10’da yazıldığg haliyle değerlendirme:

Bestekâr eserin meyan bölümüne klasik Uşşak makamında pek görülmeyen, daha çok Gerdaniye makamının özellikleri arasında ifade edilen gerdaniye perdesini kullanarak giriş yapmıştır. Birinci ölçü ve ikinci ölçüdeki eviç perdesine kadar olan bölümde nevâ perdesinin üzerinde uş̧ak geçkisi yapılacağı hissi verilse de nevâ ve dik hisar perdeleri kullanılmadığından böyle bir geçkiden söz edemiyoruz. Bununla beraber ikinci ölçünün sonunda gerdaniye ile nevâ perdesi arasında hicaz aralığı kullanarak nevâ üzerinde hicaz çeşnisi yapıldığını ifade edebiliriz. Üçüncü ölçüde çargâh perdesine düşülüp nikriz 5 'lisi elde edilmiş ancak tiz segâh perdesine kadar olan bölümde eviç perdesinden feragat edilmiştir. Şayet bu bölümde eviç perdesi kullanılmı̧̧ olsaydı çargâh üzerinde Neveser makamına geçki yapıldığını söylememiz mümkün olacaktı. $\mathrm{Bu}$ aralıklar Uşşak makamında her ne kadar kullanılmasa da bestekârın bu aralıkları son ölçüdeki hüseynî perdesine kadar kullandığını görmekteyiz.
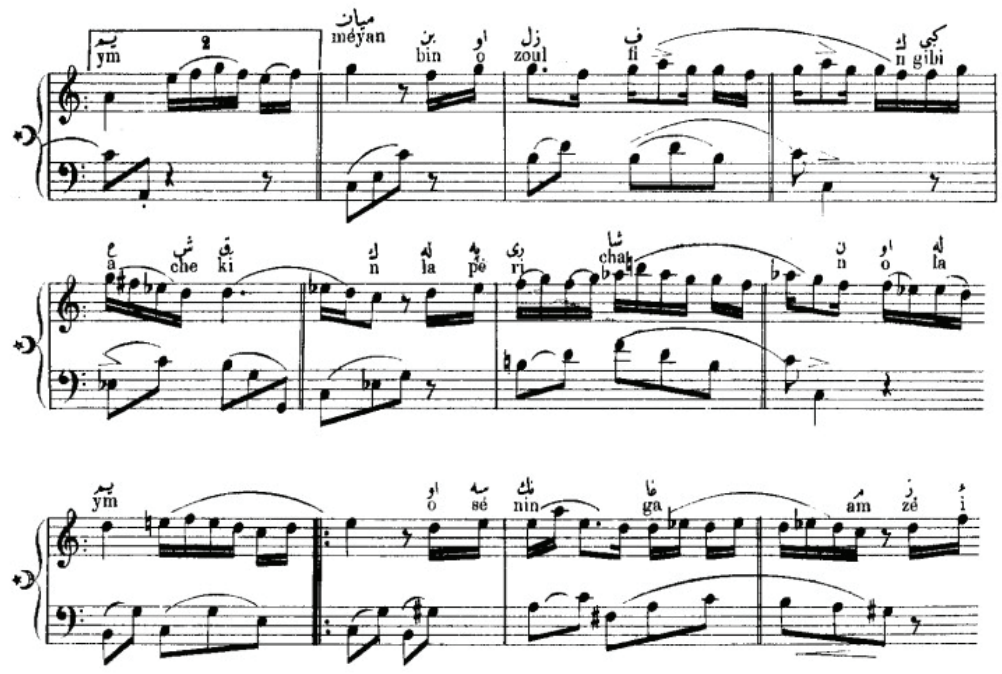

Şekil 11. Chant Turc (Türkçe Şarkı) başlığıyla hazırlanmış Fransızca nota mecmuasındaki C. Guatelli tarafindan armonize edilerek Hakkâk Servitchen Taş ve Hurufât Matbaası'nda basılan Hacı Emin imzalı nüshadaki meyan bölümü. 
Şekil 11'deki nüshaya göre değerlendirme:

1890'lı yıllarda yayınlandığını değerlendirdiğimiz bu nüsha ile Şekil 10'da bulunan nüsha arasındaki en önemli fark donanımında herhangi bir işaretin bulunmamasıdır. Bestekârın telif ettiği Bergüzâr-1 Edhem Yahud Ta’lim-i Usûl-i Mûsikî (1307) adlı eserin 9. sayfasında bulunan Sadaların Alaturka İsimleri bölümündeki tabloda segâh ve eviç perdeleri tam ses olarak tasnif edilmiştir. Bu nedenle şekil 11'deki nüshada herhangi bir donanımın yazılmaması gayet doğaldır. Bu nüshadaki bûselik ve acem perdelerini segâh ve eviç perdeleri olarak değerlendirmek gerekir. Eserin meyan bölümünün analizini buna göre yapacak olursak şu hususların altını çizmemiz gerekir;

Bestekâr eserin meyan bölümüne girişte bir önceki ölçüde vurguladığı hüseynî perdesini gerdaniye perdesi ile daha da güçlendirerek muhayyer perdesine kadar seyre devam etmiştir. Burada eviç perdesinin kullanılmasıyla beraber hüseynî perdesi üzerinde Uşşak 4'lüsü meydana gelmiştir. Meyana hüseynî perdesi üzerinde Uşşak göstererek giriş yapan bestekâr ikinci ölçünün sonunda gerdaniye ile nevâ perdesi arasında Hicaz aralığı kullanarak nevâ üzerinde Hicaz, üçüncü ölçüde çargâh üzerinde Nikriz çeşnilerine yer vermiştir. Muhayyer perdesine kadar olan bölümde eviç perdesini de kullanarak çargâh üzerinde Neveser makamı dizisini meydana getirmiştir. Son ölçüde saz bölümüne kadar, nevâ perdesi üzerinde Hicaz'lı kalış yaparak meyan bölünü bitirmiştir.

\section{Gönlüm Yine Bir Âteși Hicrâne Dolaștı (Nihâvend Șarkı)}

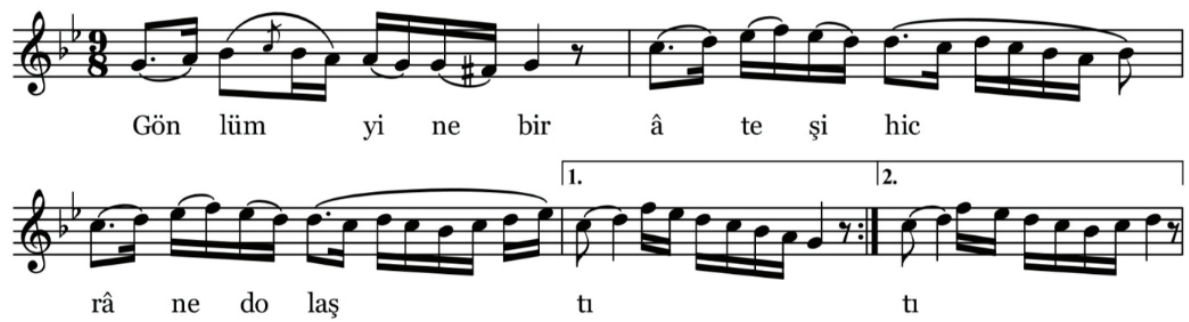

Şekil 12. Eserin 5 ölçü ile gösterilen zemin bölümü.

Şarkı aksak usulünde bestelenmiştir. Giriş bölümüne Nihâvend makamının karakteristik özelliği olan rast perdesinden başlangıç yapılmıştır. İlk ölçüde rast, dügah ve kürdî perdeleri dolaş1lıp yedeni olan ırak perdesi de gösterilerek rast perdesinde kalınmıştır. İkinci ölçüye çargâh perdesiyle başlanmı̧̧ ve acem perdesine çıkılarak nihayetinde kürdî perdesine gelinmiş ve bu perdede asma kalış yapılmıştır. Üçüncü ölçüde de yine ikinci ölçüde olduğu gibi çargâh perdesiyle seyre devam edilmiş, nevâ perdesi etrafında dolaşılarak bu perde güçlendirilmiştir. Nitekim birinci dolap olan dördüncü ölçüde makamın güçlüsü olan nevâ perdesi tutulmuş ve saz bölümünde karara kadar Bûselikli iniş yapılmıştır. İkinci dolapta ise yine nevâ perdesi tutularak seyre devam edilmiş, saz bölümüyle makamın güçlüsü olan nevâ perdesi üzerinden nakarata bağlantı yapılmıştır. 


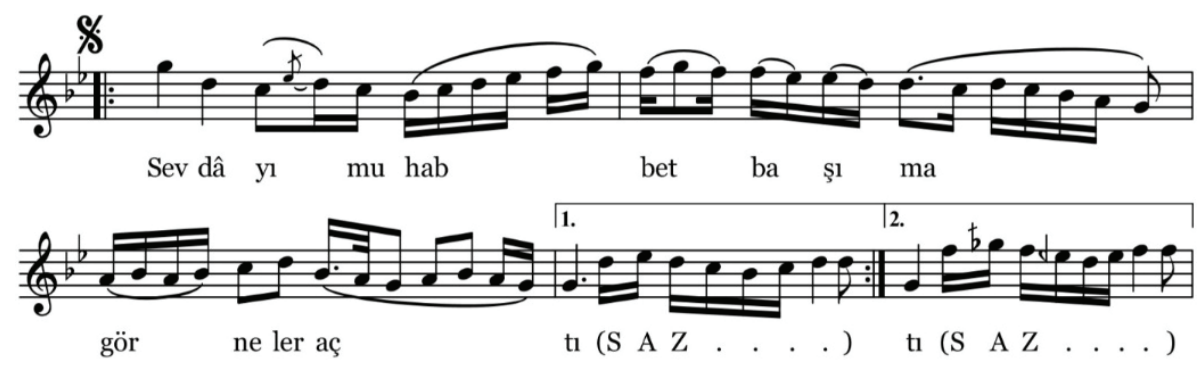

Şekil 13. Eserin 5 ölçü ile gösterilen nakarat bölümü.

Eserin nakarat bölümünde Nihâvend makamının dizisinde bulunan rast, dügâh, kürdî, çargâh, nevâ, nim hisâr, acem ve gerdâniye perdelerinin tamamını kullanmıştır. İlk ölçüye gerdâniye perdesinden nevâ perdesine düşüşle başlanmış, devamında bu iki perde arasındaki kürdî 4'lüsü de gösterilerek ikinci ve üçüncü ölçüyle birlikte diziyi oluşturan tüm sesler kullanmış ve rast perdesindeki buselik 5’lisi işlenerek Nihâvend seyri devam ettirilmiştir. Dörcüncü ölçüdeki dolap bölününde nevâ perdesi üzerinden dönüş yapılmıştır. Ancak meyan bölümüne geçişi sağlayan ikinci dolap bölümünde mahur ve dik hisar perdeleri kullanılarak nevâ perdesi üzerinde Sabâ geçkisi tercih edilmiştir. Bu geçki Nihâvend makamında bestelenmiş eserlerde az da olsa görülen bir geçkidir. Bestekârın bu geçkiyi kullanması Nihâvend makamı ile ilgili kendine has bir bakış açısının olduğunu ortaya koyar.

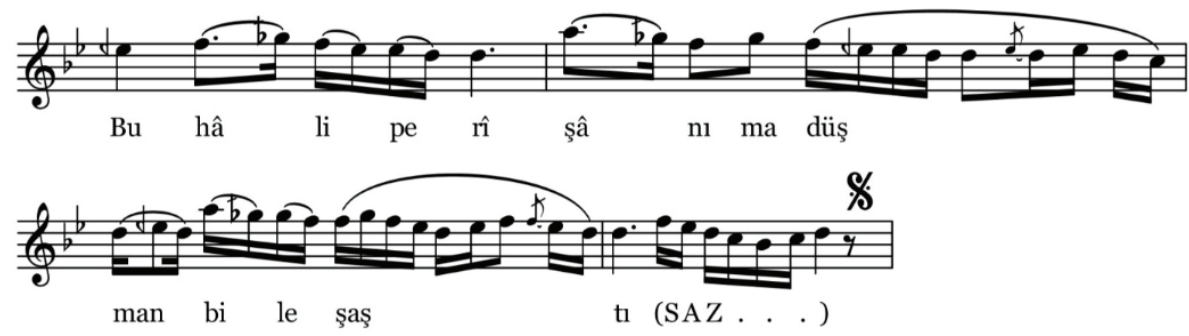

Şekil 14. Eserin 4 ölçülük meyan bölümü.

Eserin meyan bölümüne nevâ perdesi üzerindeki Sabâ ile devam edilmiştir. Birinci ölçüye dik hisar perdesiyle giriş yapılmış, K-S-S aralıklarına sahip Sabâ 4'lüsü işlenerek nevâ perdesinde kalınmıştır. İkinci ve üçüncü ölçüde yine nevâ perdesi üzerindeki Sabâ devam ettirilmiş ve nihayetinde nevâ perdesine tekrar gelinmiştir. Dördüncü ölçüde ise dik hisar perdesi kaldırılarak nim hisar perdesine dönüş yapılmış, kürdî perdesine düşülerek yeniden rastta buselik 5'lisi üzerine nevâda kürdî 4'lüsünün eklenmesinden müteşekkil Nihâvend duygusuna girilmiştir.

\section{Değerlendirme ve Sonuç}

Bestekârın “Zirgüleli Sûzinak Tevşih” eserinin zemin bölümünde nevâ perdesinin üzerinde Hicaz 5'lisinin kullanılarak muhayyer perdesine kadar çıkılması, nakarat bölümünde nevâ perdesinde Uş̧̧ak geçkisine yer verilmesi, meyan bölümüne eviç perdesiyle giriş yapılması gibi 
hususlar bestekârın makama kendine has yorum kattığını düşündürmektedir. Bu tür yaklaşımların makamın zenginleşmesine katkı sağlayacağı muhakkaktır. Eserde her ne kadar çargâh perdesinde Nikriz, segâh perdesinde Hüzzam gibi çeşniler tercih edilmese de analiz bölümünde bahsettiğimiz hususlar haricinde makamın klasik anlayışa uygun olarak işlendiğini söyleyebiliriz.

Uşşak makamındaki “Cumhur İlahi” eserinin genelinde güçlü bir uşşak hissinin hâkim olduğunu, nakarat bağlantılarında nim hicaz perdesinin kullanıldığını, segâh, çargâh ve neva perdelerinde asma kalışlar yapıldığını, yerinde Sabâ geçkisine yer verildiğini, yegâh perdesinde Rast yapmak gibi genişlemelere yer verilmediğini ifade edebiliriz.

“Bir Nigâh Et Bana Çeşmânına Hayrân Olayım” adlı Uş̧̧ak Şarkıda bestekârın analiz bölümünde ifade ettiğimiz pek çok geçki ve çeşniye yer verdiğini, hüseynî perdesine fazlaca vurgu yaptığını, bu duruma klasik Uş̧̧ak eserlerde rastlanılmadığını söyleyebiliriz.

“Gönlüm Yine Bir Âteşi Hicrâne Dolaştı” adlı Nihâvend Şarkıda buselik 5’lisinin üzerinde durulduğunu, meyan bölümünde neva perdesi üzerinde bu makamda pek kullanılmayan Sabâ geçkisine yer verdiğini, yegâh perdelesinde yapılan genişlemelere yer vermediğini söyleyebiliriz.

Sonuç olarak analizini yaptığımız 4 bestesine göre Müştakzâde Hacı Edhem Efendi kendine has bir tavır ve tarz ortaya koymuştur. Müellifi olduğu Bergüzâr-ı Edhem Yahud Ta'lim-i Usûl-i Mûsikî adlı eserde klasik nazariyata dair bilgiler aktarmış ancak bestelerinde kullandığı makamları işlerken klasik eserlerde pek rastlanmayan geçki ve çeşnilere yer vermiştir. Bu çeşit yorumların onun çok yönlü mûsikî anlayışına sahip olduğuna işaret ettiğini söyleyebiliriz. Dinî ve ladinî bestelerinin bazılarını yayınlayarak dönemin mûsikî anlayışına ve repertuvarına katkı sağladığı da ifade edebiliriz.

\section{Kaynakça}

Edhem Efendi, Ş. (1307). Bergüzâr-ı Edhem Yahud Ta’lîm-i Usûl-i Mûsikî. Bahriye Matbaası.

Feyzi, A. (2014). Şeyh Edhem Efendi Tarafindan Yazılan "Bergüzar-1 Edhem Yahud Talim-i Usûl-û Musık̂” Adlı Güfte Mecmuası Üzerine Müzikolojik Bir İnceleme. Ekev Akademi Dergisi, 59.

Güdek, B., \& Kılıç, A. (2016). Muzıka-1 Hümayun'dan Günümüze Klasik Batı Müziğinin Türkiye'deki Tarihsel Gelişimi. The Journal of Academic Social Science Studies, 47. https://doi.org/10.9761/ JASSS3399

İhsanoğlu, E., Şeşen, R., Gündüz, G., \& Bekar, M. S. (2003). Osmanlı Mûsikî Literatürü Taribi. İslâm Tarihi, Sanat ve Kültür Araştırma Merkezi, IRCICA.

İnal, İ.-E. M. K. (1958). Hoş Sadâ Son Asır Türk Mûsikîşinasları. Maarif Basımevi.

Karagül, S. (2019). Osmanlı Imparatorluğu’nda Modern Müziğin Doğuşu: Musika-ı Hümayun [Y.L. Tezi]. Hacettepe Üniversitesi Sosyal Bilimler Enstitüsü.

Koca, F. (2017). XX. Yüzyıl Hâfız Mûsikîş̧inasları-1 (Mans Medya Yapım Ltd. Şti.).

Kutlay Baydar, E. (2010). Osmanlıda Görevli İki İtalyan Müzisyen: Giuseppe Donizetti ve Callisto Guatelli. Zeitschrift für die Welt der Türken, 1(2).

Özcan, N. (1994). Edhem Efendi, Müştakzâde. Içinde TDV İslam Ansiklopedisi (C. 10).

Özcan, N. (2006). Muzıka-yi Hümâyun. Içinde Türkiye Diyanet Vakfi İslâm Ansiklopedisi (C. 31). 
Öztuna, Y. (1990). Büyük Türk Mûsikîsi Ansiklopedisi (C. 1). Kültür Bakanlı̆̆1.

Rona, M. (1970). 20. Yüzyıl Türk Musikisi. Türkiye Yayınevi.

Sefer, E. (2012). XIX. Yüzyılda Batılılaşmanın Türk Musikisine Etkileri [Y.L. Tezi]. İstanbul Teknik Üniversitesi Sosyal Bilimler Enstitüsü.

Sezen, A. (1992). Türk Müziğinde Nota Yayımcıllğı (1875-1928) [Y.L. Tezi]. İstanbul Teknik Üniversitesi Sosyal Bilimler Enstitüsü.

Y1ldırım, E. (2019). 19. Yüzyıl Sonu Osmanlı Toplumunda "Tercüme” Eserlerin Tanıtımı Üzerine Betimleyici Bir Inceleme: Kitap̧̧ı Arakel Katalogları [Y.L. Tezi]. İstanbul Okan Üniversitesi Sosyal Bilimler Enstitüsü. 


\section{SÛZINÂK TEVŞİH \\ (Zirgüleli)}

Usül: Evsat

Güfte: Bilinmiyor Beste: Șeyh Hacı Edhem Efendi

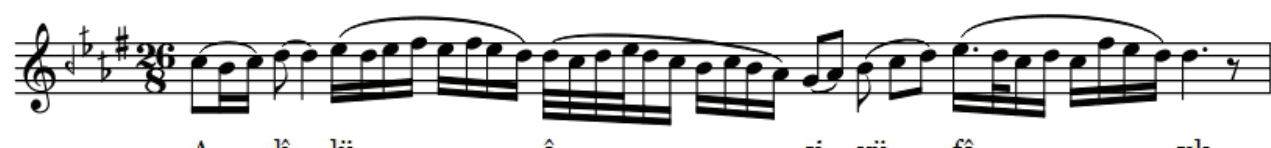

A lî lü

â

si vü

slk
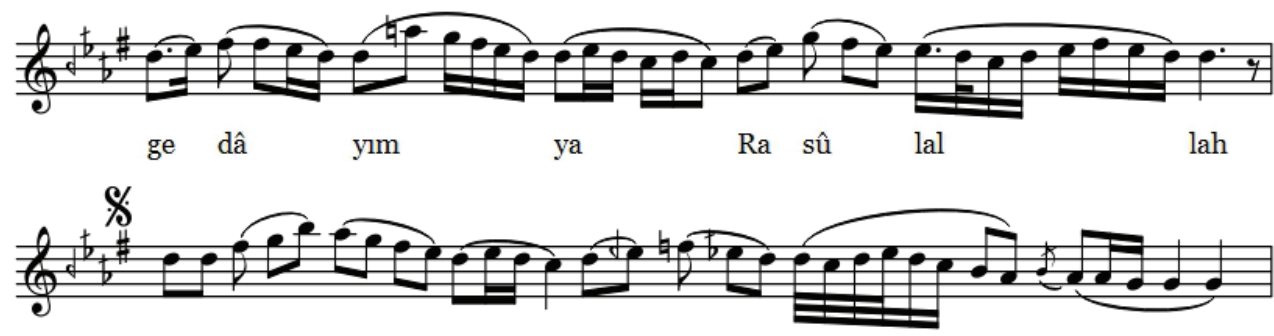

Bü tün â lem le re nef

ret
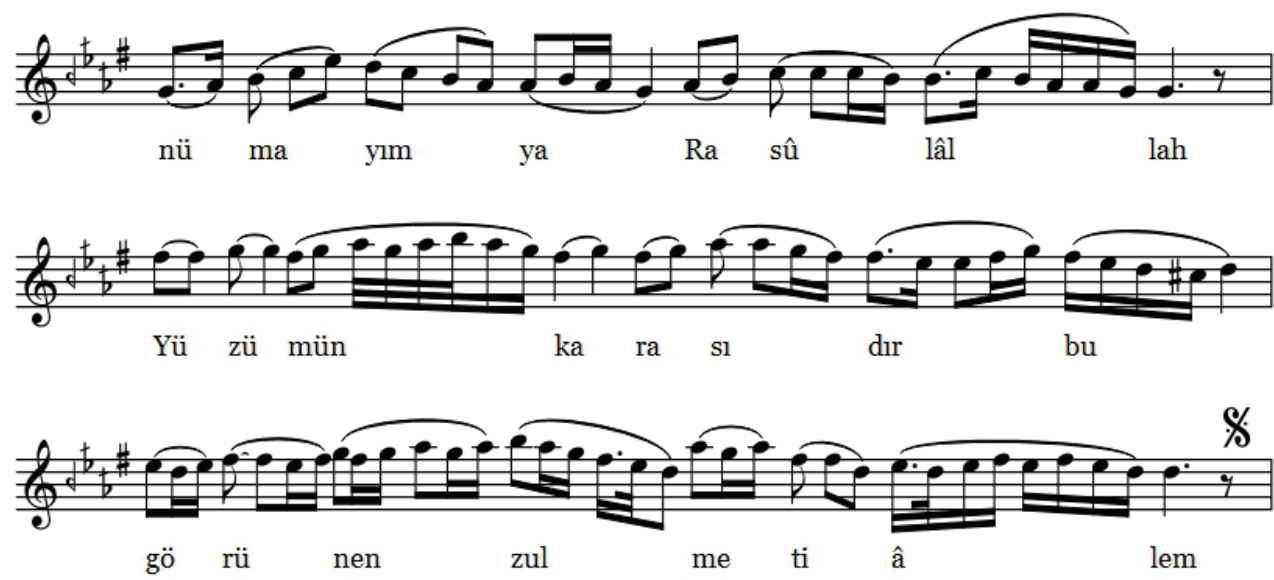

Alil-ü âsi vü fâsık gedâyım ya Rasulallah

Bütün âlemlere nefret nümâyım ya Rasulallah

Yüzümün karasıdır bu görünen zulmet-i âlem

Anınçün șems-i vechinden cüdâym ya Rasulallah

Şekil 15. Zirgüleli Sûzinak Tevşih Notası 


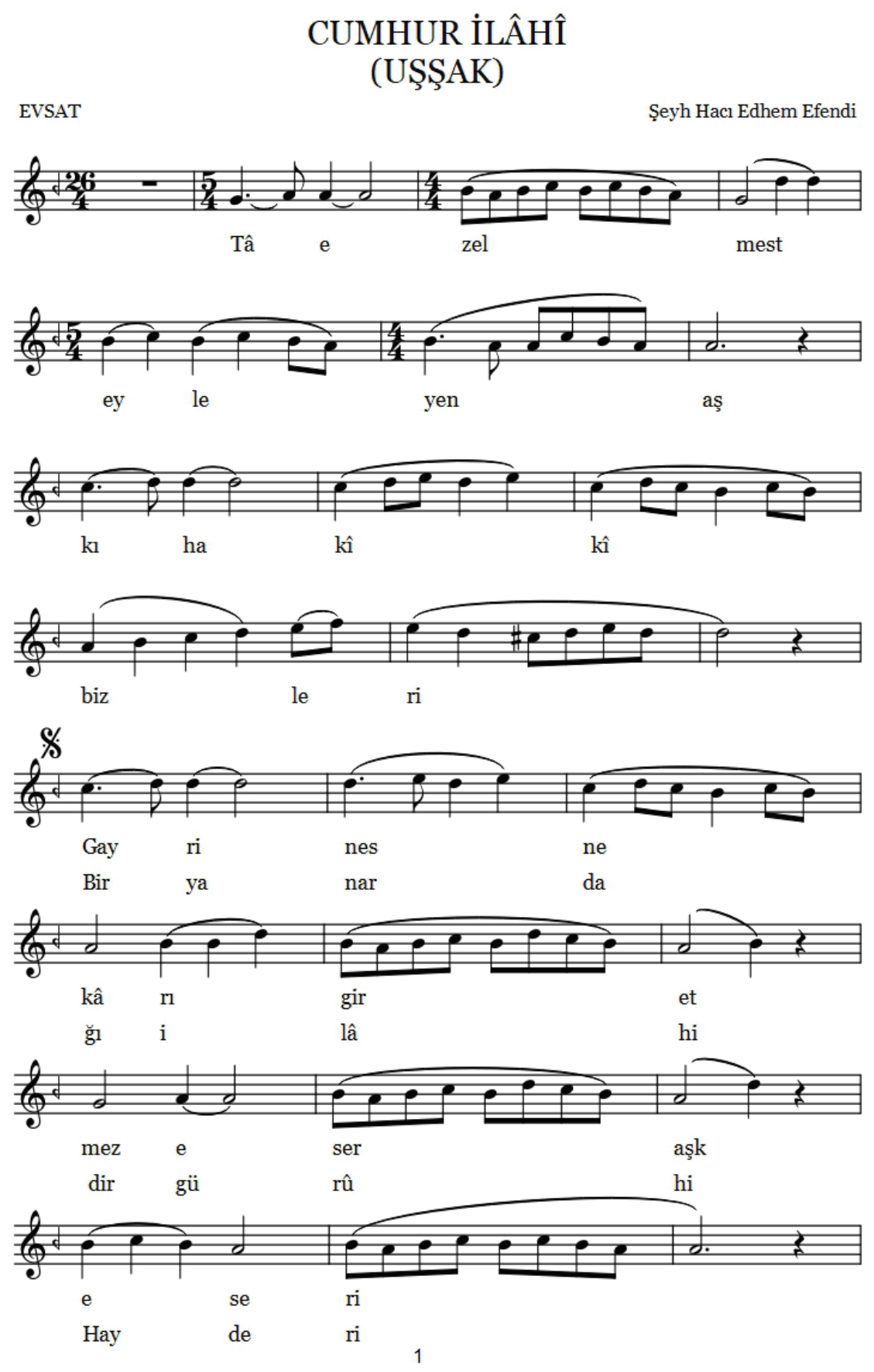

Şekil 16. Cumhur İlâhî (Uşşak) Notası. (Birinci Sayfa) 

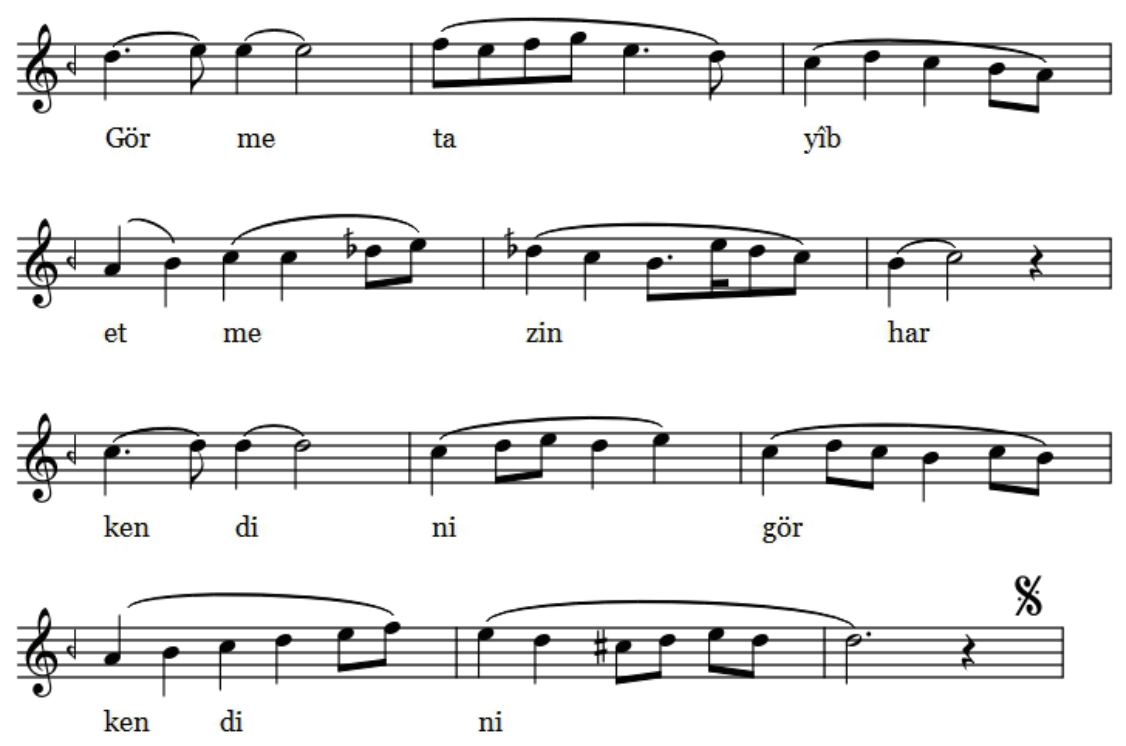

Tâ ezel mest eyleyen așk-ı hakîkî bizleri Gayri nesne kârgir etmez eser aşk eseri

Görme ta'yib etme zinhâr kendini gör kendini Bir yanardağ-1 ilâhidir gürûh-i Hayderî

Sanmayın ușşâkı nây u mey ile sarhoș olur Belki bu hâlet devâmı derd-i aşkın bedteri

Tâ ezelden ettim ikrâr böyledir ahdim benim Râh-1 aşkım bâb-1 Rahman dönmezsem aslâ geri

Redd-i bâb etmez emînim ehl-i beyt-i müctebâ Halka-i bâba sarıldım ben o şâhın kemteri

Ger dilersen bezm-i aşkda yâd ola nâmın senin Mürşîd-i irfâna teslim eyle nefs-i ahkari

Ârif-i billâh olursun bend-i ilâhiyi tutan Sonra nâdim olmadan kır kibrini bul rehberi 


\section{BİR NİGÂH ET BANA ÇEŞMÂNINA HAYRÂN OLAYIM (UŞŞAK ŞARKI)}

Usül: Aksak

Güfte: İsmail Sefa Bey Beste: Seyh Edhem Efendi

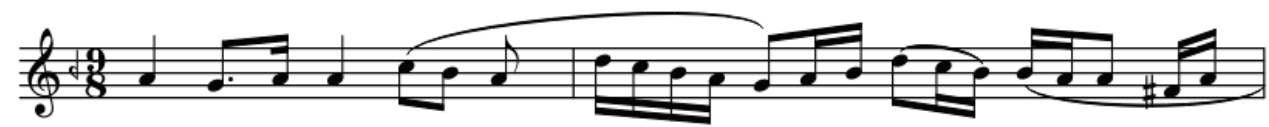
Ah Bir ni gâh et

ba na çeş

mâ
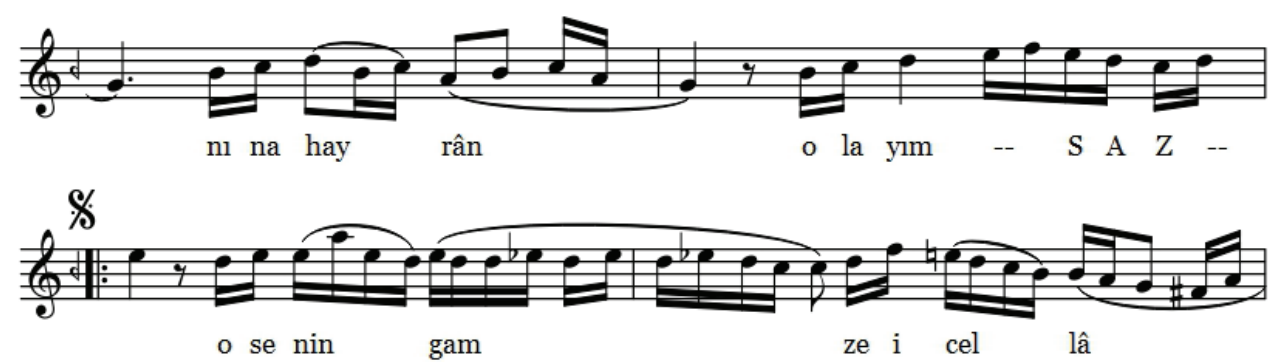

1.

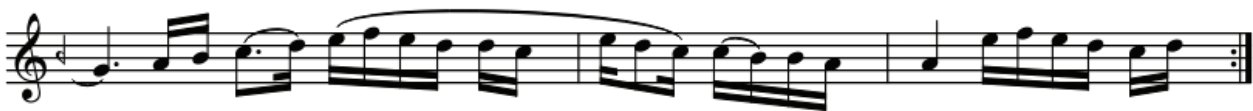

dı na kur ban

$\begin{array}{llllllll}\text { o } & \text { la } & \text { yım } & -- & \text { S } & \text { A } & \text { Z } & \text {--- }\end{array}$
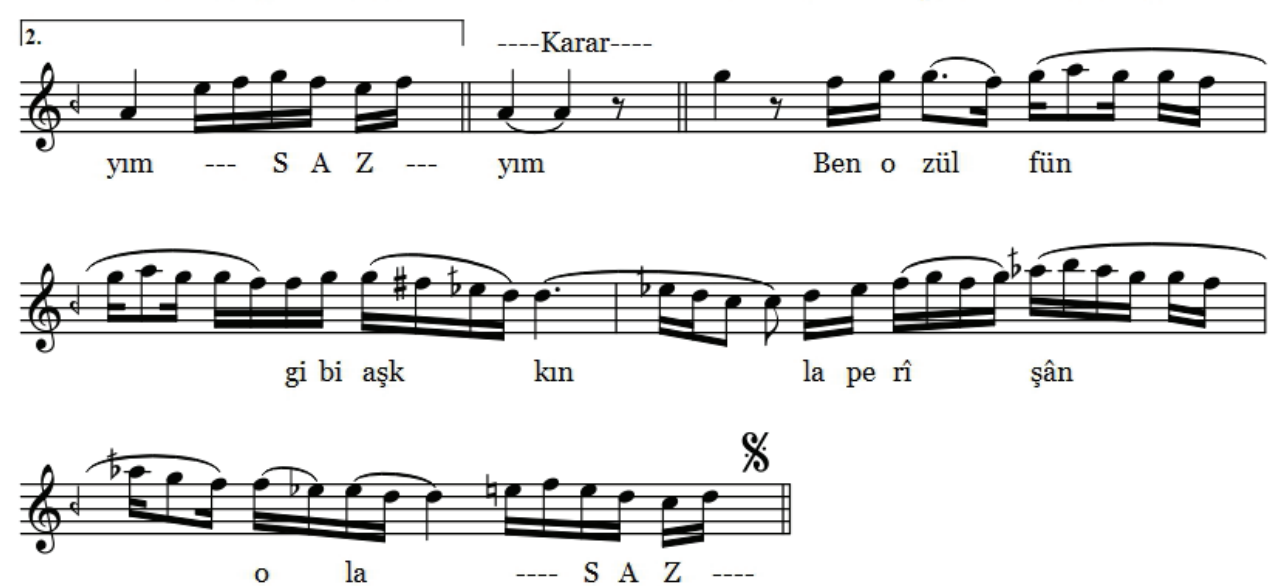

Bir nigâh et bana çeșmânına hayrân olayım

O senin gamze-i cellâdına kurban olayım

Perçemin rûyine bir başka terâvet vermiş

Ben o zülfün gibi așkınla perâșân olayım

Aldanır hem de görenler ona sünbül dermiş

O senin gamze-i cellâdına kurban olayım

Ah o gamzen nice âșlklarını öldürmüss

O senin gamze-i cellâdına kurban olayım

Şekil 18. Bir Nigâh Et Bana Çeşmânına Hayrân Olayım (Uşşak Şarkı) Notası. 


\section{GÖNLÜM YİNE BİR ÂTEŞ-İ HİCRÂNE DOLAŞTI \\ (Nihavend Şarkı)}

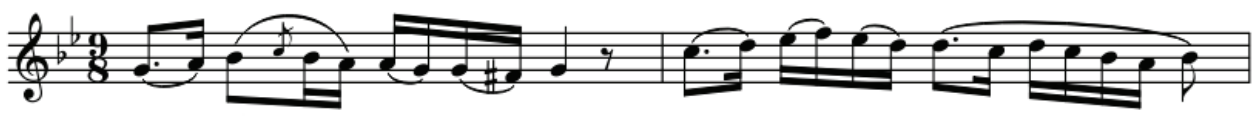

Gön lüm yi ne bir â te şi hic

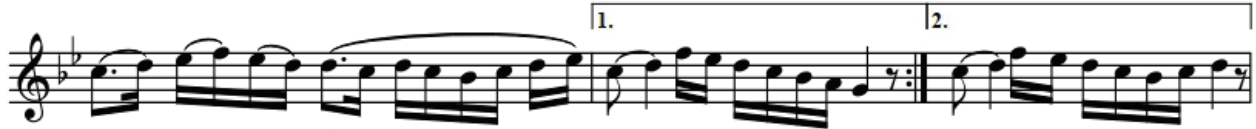

râ ne do laș

t

th
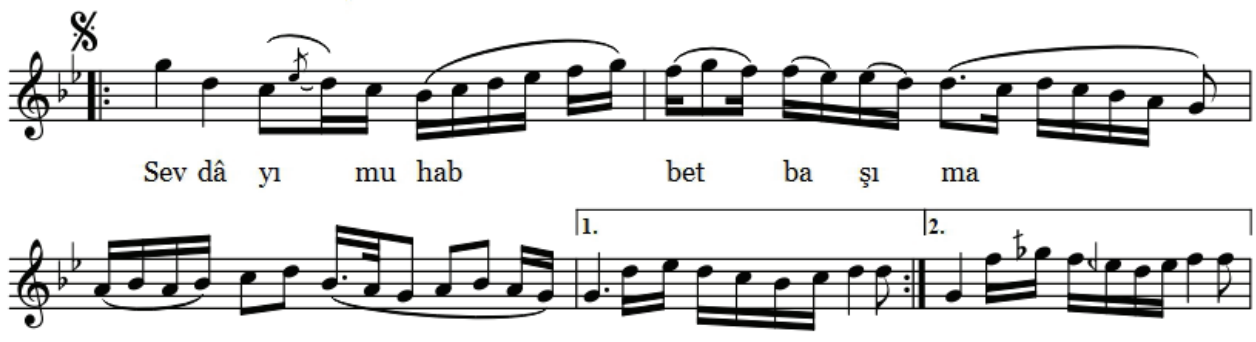

gör ne ler aç

t $(\mathrm{S} \mathrm{A} \mathrm{Z} \mathrm{...} \mathrm{.} \mathrm{)} \mathrm{t}(\mathrm{S} \mathrm{A} \mathrm{Z}$... . )
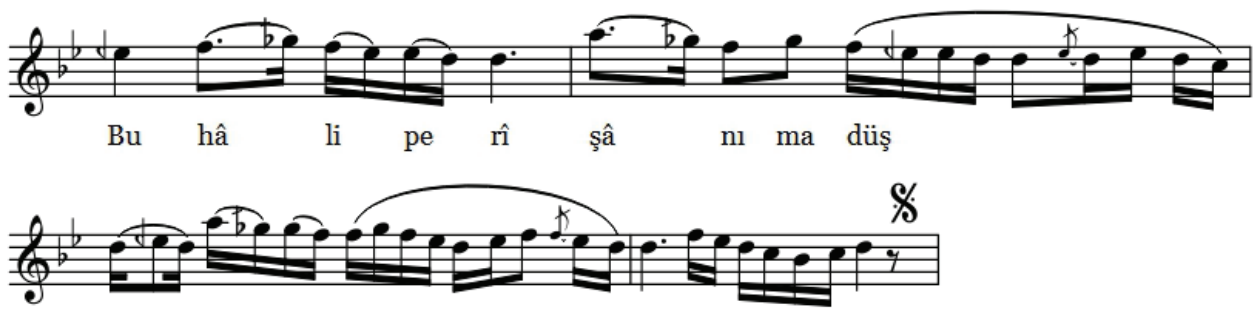

man bi le şaş to (SAZ . . .)

Şekil 19. Gönlüm Yine Bir Âteşi Hicrâne Dolaştı (Nihâvend Şarkı) Notası. 


$$
\text { NR? }
$$

